\title{
Research on the Application of Narrative Teaching Method in College English Oral Teaching
}

\author{
Yang Xiulan \\ Xi'an University of Arts and Sciences, Xi'an, China
}

Keywords: Narrative Teaching Method, College English Oral Teaching, Application

Abstract: Narrative teaching method is a kind of teaching method, which is a comprehensive description of the application of narrative teaching method in college English oral teaching. There are two reasons why it should be applied to college English oral teaching. First, this method has gained more practice and application in foreign language spoken language teaching. It has accumulated certain experience and has a practical basis. The second is to improve the effectiveness of college English oral teaching, especially in foreign language. Besides, this paper also discusses the application themes and characteristics of narrative teaching method in college English oral teaching. Combined with the current teaching materials, it provides a variety of support and arguments on how to use this method in college English oral teaching.

\section{Introduction}

Narrative teaching method is a comprehensive teaching method, which contains many specific contents. Liu Jia thinks that it is an perfect combination of approach, method and technique in his "narrative teaching method and its application in college English teaching". The narrative teaching method has received a certain degree of advancement. This new teaching mode not only focuses on the different cognitive levels and abilities of students, but also considers the influence of students' emotional factors on language acquisition, and focuses on cultivating students' application and innovation ability. College English oral teaching research refers to non-English professional English teaching here. In the past, scenario teaching method, task method, target teaching, oral teaching five-step method, etc. have been proposed, but how to improve the effect of college English oral teaching is still a very important problem.

The narrative teaching method advocates the use of narrative methods in foreign language teaching, and design or guide teachings or parts of the teaching as much as possible using the narrative form. Students will bring themselves in stories, mobilize their own understanding, use imagination, interpret emotions, and liberate the mind, so as to complete the learning process in the process of narrative. Narrative teaching method also refers to a teaching method, including various specific teaching techniques, which is a combination of approach, method and technique. In dictionary, approach refers to the method, with the meaning of proximity. Method also refers to measure, with the meaning of processes of doing something. This method and process is often regular, step-by-step, and systematic. Technique refers to skill, technology and craft. The meaning of these three words is included in the narrative teaching method. It is very new to explore its 
application in college English oral teaching. It not only expands the new way of college English oral teaching, but also provides a new opportunity for improving the teaching effect and mobilizing students to fully engage in oral English learning.

\section{The Basis of the Application of Narrative Teaching Method in College English Teaching}

\subsection{Theoretical Basis of Bruner and Narrative Teaching Method}

The anthropologist Bruner believes that human thinking can be divided into narrative and paradigm thinking (scientific thinking). Humans are accustomed to experiencing life through stories, summing up experiences, and making up possible worlds. The narration of "Bruner narrative education thought and its enlightenment" is the "circulation currency" of culture, which is the basic way to understand others. The self is also constructed in narrative. Education must enable students to construct a world of their own in the vast cultural land. Therefore, it is necessary to develop students' narrative thinking ability and use narrative methods in daily knowledge teaching. Bruner's narrative education thought has important enlightenment significance for educational practice and research at all levels.

\subsection{Theory of Cognitive Psychology}

Through the study of cognitive psychology, we understand that human life is a story-based process, and the authenticity of human events and thoughts can only be expressed and stimulated through stories. This is very important in college English oral teaching. The human event is closely related to the person, that is, the learner itself, which affects the learner's desire. This is precisely the goal of the oral teacher to introduce into the classroom.

\subsection{Theory of Cognitive Linguistics}

Cognitive linguistics believes that in the process of mastering language, people must first learn the usage of narrative. Narrative discourse is more noticeable than non-narrative discourse, more conducive to cognition and foreign language learning. In college English oral teaching, the topic is closely related to current and future life. Narrative self-expression is an important ability. To express your own life and thoughts in your own language is exactly what students should practice in spoken English.

\subsection{Theory of Narrative}

Narrative theory believes that people are born to be the storyteller, and the story provides consistency and continuity for people's experiences. Some philosophers have elevated the narrative to the height of human cognition and the basic way of expressing the world.

\subsection{Theory of Foreign Language Teaching}

There are two main points of foreign language teaching. First is the value of cultural teaching, that is, to cultivate students' cultural awareness. Second, narrative is a fairly interesting process that applies to any level of language and teaching. In the process of learning the language, human beings must be the first to learn the narrative. For example, in oral expression, we have to learn to distinguish between complaints and statements, which is an important ability in cultural acquisition. 


\section{Themes Related to Narrative Teaching Method in College English Oral Teaching}

\subsection{Application Themes that Narrative Teaching Method May Involve in Oral English}

Teaching in Junior Colleges

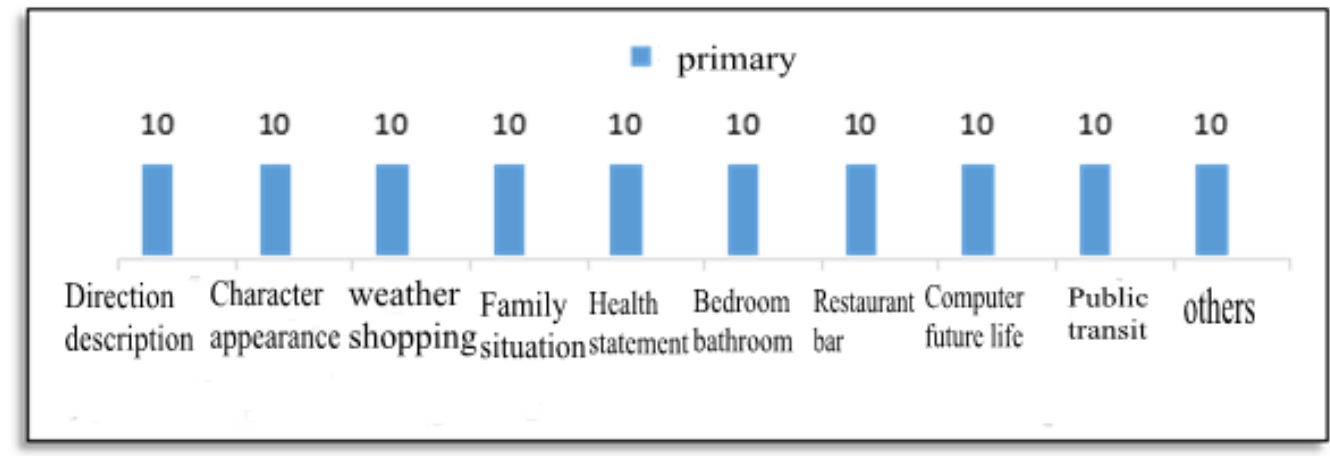

Figure 1 Application topic table of narrative teaching method in oral English teaching in junior colleges

Direction description and find direction when lost. The narrative method is used in the description of the orientation, and has excellent effects. The learner of the language can quickly grasp the foreign language description of the direction, and the practical application is very strong.

A description of the appearance of the character. For example, you will find this method is very interesting through the mutual description of the learners in the theme of "My good friend", "My teacher" or even "Her boss", "Police and thief", etc.

Weather and shopping. The continuous expression practice is very effective with the narrative method when describes the weather.

Family situation

Health statement. Health issues also include a simple description of the condition, which is also a necessary exercise.

Bedroom, bathroom, room, living room, kitchen description, etc.

Restaurant and bar

Computer and future life

Public transit

3.2 Application Themes that Narrative Teaching Method May Involve in Oral English Teaching in Middle and Advanced Colleges

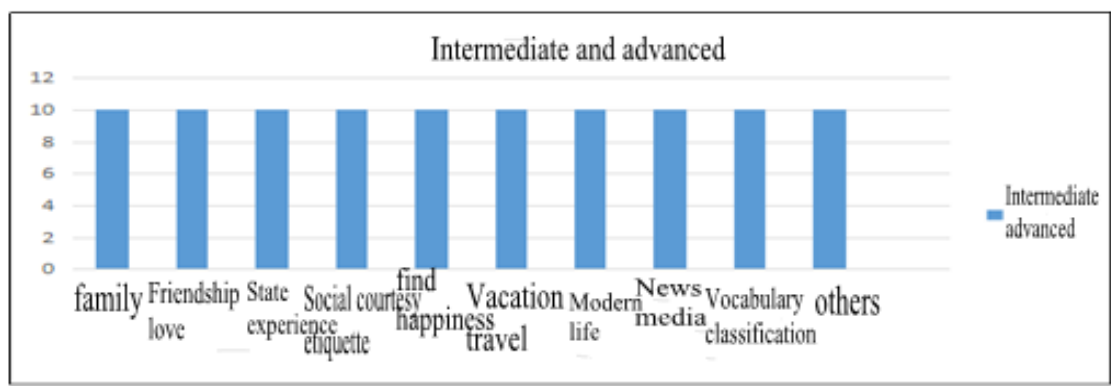

Figure 2

Family theme. Family theme is an eternal theme that everyone needs, and everyone has an 
experience. Therefore, when uses the narrative method, learners are psychologically prepared.

Friendship and love. Friendship and love are things that everyone is eager to pursue, so using narrative will show different things.

State your own experience, that is, tell your own story

Social courtesy and etiquette

Looking for happiness. The theme of life is to find happiness, but people at different stages will give different answers. Therefore, the narrative method can show the learner's self-spirit and pursuit.

Vacation travel. Vacation travel involves amateur life and easy access to narrative themes. Narrative news stories are also a good way to exercise your mind and practice spoken English.

\section{Modern life}

Vocabulary classification teaching. For example, "a fun dinner" may involve all the usual foods. Themes such as "a wedding," "a car accident," "an attraction," and so on may involve a large amount of vocabulary. Narrative is the process of vocabulary application.

\section{News media}

The above topics have been selected with reference to the new foreign language college English textbooks of the Foreign Language Teaching and Research Press.

\section{The Application Characteristics of Narrative Teaching Method in College English Oral Teaching}

This paper discusses the application of college English oral teaching from the perspective of narrative to improve the effectiveness of oral teaching. Chen Caifen also mentioned the viewpoint of narrative teaching method in the study of the effectiveness of oral English teaching in college English teaching from the perspective of narrative. Xu Jinfen believes that narrative research is based on the story of oneself or others as a research content and object, to tell, listen and reflect on such stories as a qualitative research paradigm of the main form of research. Deng Zhiyong believes that narrative is universal, and each language genre is inseparable from narrative. Zhai Dongchang and others believe that educational narrative research is the combination of teaching stories and reflection or commentary. We can approach the truth of everyday education through stories, oral, on-site observations, diaries, interviews, autobiographies or biographies, and even letters and literature analysis of educational experiences.

\subsection{Narrative Teaching Method Adds a Sense of Vision to the Classroom}

In narratives, in order to express clarity, many descriptive adjectives and adverbs are often used, so the listener feels very visual.

\subsection{Narrative Teaching Method Has Natural Clues to Find}

Whether it is orientation description or narrative of personal experience, the clue is either a place, a time, or a character, so it has a natural sense of clue. The organization is easy to sort out and the logic is clear. It has the characteristics that the speaker can easily sort out the ideas and the listeners can easily understand, which reduce the difficulty of communication.

\subsection{Narrative Teaching Method Adds Interest to College English Speaking Classroom}

The narrative method increases the individual's chance to express themselves, the non-preparation of the classroom, and highlights the differences of the individual, thus improving 
the fun of the classroom.

\subsection{Narrative Teaching Method Reduces the Difficulty of Memorizing Foreign Languages and Increases the Connection of Knowledge}

Narrative things are all in the same subject or event, thus increasing the connection and closeness of knowledge.

\section{Conclusion}

When advocating a teaching method, we do not deny other ways, just as we emphasize the importance of the quality of the air, and can not stop drinking water. Our goal is to better and faster promote the effectiveness of college English oral teaching. According to Bruner's view and understanding of learning, the essence of learning is that one person connects the same kind of things and organizes them into structures that give them meaning. Narrative teaching is a process of self-relation and self-reconstruction. In short, Bruner believes that the learning of knowledge is to form a certain knowledge structure in the minds of students. This kind of knowledge structure is composed of basic concepts, basic ideas or principles in subject knowledge. The structural form of the knowledge structure is constructed by the coding method of the human coding system and can be expressed by three reproduction modes. The value of a knowledge structure depends on its ability to simplify the data, generate new propositions, and enhance the use of a knowledge. The application of narrative teaching method in college English oral teaching is a way to accept a knowledge structure, simplify data and enhance the use of knowledge. It is beneficial for non-professional college students to learn English.

\section{References}

[1] Cai Chun. Why Narrative Stories Can Be Called Research--Discussion on the Basic Theoretical Issues of Educational Narrative Research [J]. Journal of Capital Normal University (Social Science Edition), 2008 (4): 125-130.

[2] Chen Zhenzhong. Discussion on Some Theoretical Issues of Educational Narrative Research [J]. Shanghai Education and Research, 2005 (9): 31-33.

[3] Ke Zheng and Tian Wenhua. Another Narrative of Narrative and Narrative Research [J]. Contemporary Education Science, 2007 (14): 10-14.

[4] D. Jane Crandinin and F. Michael Connelly edited and Zhang Yuan Translated. Narrative Inquiry: Experience and Story in Qualitative Research [M]. Beijing: Peking University Press, 2008.

[5] Ma Yibo and Zhong Hua. Narrative Psychology [M]. Shanghai: Shanghai Education Press, 2006.

[6] Shen Dan. A Talk about "Narrative" or "Statement" [J]. Foreign Literature Review, 2009 (3).

[7] Zhang Anlv and Liu Anhong. Cognitive Psychology and Foreign Language Teaching [J]. Foreign Languages, 2010 (10).

[8] Deng Da and Xiong Muqing. The Narrative Expression of Foreign Language Teaching-A Perspective of Teaching Theory [J]. Foreign Languages, 2010 (3).

[9] Liu Jia. Application of Narrative Teaching Method in English Vocabulary Teaching [J]. Foreign Languages, 2011 (3).

[10] Chen Caifen. Research on the Effectiveness of Oral English Teaching in College English from the Perspective of Narrative [J]. Journal of Xi'an International Studies University, 2018, 26 (03): 79-82.

[11] Carroll D David W. Psychology of Language [M]. Beijing: Foreign Language Teaching and Research Press, 2000.

[12] Cook Vivian. Second Language Learning and Language Teaching [M]. Beijing: Foreign Language Teaching and Research Press, 2000.

[13] Gee-James P. An Introduction to Discourse Analysis: Theory and Method [M]. Beijing: Foreign Language Teaching and Research Press, 2000. 